\title{
Translation and Adaptation of Thousand and One nights into Tamil
}

\author{
D. Sundararaj \\ Assistant Professor, Department of Tamil \\ KR College of Arts \& Science, Kovilpatti, Tamil Nadu, India
}

\section{OPEN ACCESS}

Volume: 8

Issue: 2

Month: March

Year: 2020

P-ISSN: 2320-2645

E-ISSN: 2582-3531

Received: 18.01.2020

Accepted: 24.02.2020

Published: 01.03.2020

Citation:

Sundararaj, D.

"Translation and

Adaptation of Thousand and One Nights into

Tamil." Shanlax

International Journal

of English, vol. 8, no. 2, 2020, pp. 46-49.

DOI:

https://doi.org/10.34293/

english.v8i2.1880

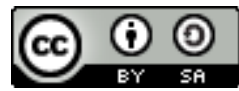

This work is licensed under a Creative Commons Attribution-

ShareAlike 4.0

International License

\begin{abstract}
The Thousand and One Nights (also called The Arabian nights) were introduced popularly to Tamil people and got a good response from both Muslims and non-Muslims, so it has been continuously translated into Tamil by different authors for over three centuries. We divided the Tamil translation of Arabian nights two, complete translation and partial translation. Sixteen complete translations and twelve partial translations were made in these three centuries. Some of the complete translations do not cover all stories of Arabian nights. The adaptation can be separated into two. The first one is to extract only the subject matter from Thousand and nights. In this way, there are a lot of short stories and novels were written in Tamil, based on the subject matter of Thousand and nights. Let us take the structure and subject matter of thousands and nights. There is a children novel in Tamil, Mayakkallan by Perisamy Thooran, which adapted the structure and subject matter of Thousand and nights. Mayakkalan, like Thousand and nights, involves many stories within a story and exemplifies magic in the subject matter.

Keywords: Thousand and One Nights, Translation, Adaptation
\end{abstract}

The Thousand and One Nights (Alf laylahwalaylah) is one of the most popular works in world literature and spawn numerous adaptations and imitations. In the modern age, it has been translated into most of the world languages. The very first modern translation was made in French by Antoine Gallandin 1717, subsequentlytranslated into major languages of the world, English, German, Russian, Chinese, Japanese, etc., and which these tales transcend cultural and linguistic boundaries. In 1825, P.GanaprakasaMudaliyar, probably from Pondicherry, translated and published the 'Arabian nights Entertainment' in twelve volumes, which had the English and Tamil version in a parallel column. This probably was the first work in Tamil related to the Arabic and Islamic countries by a Tamil, though the author was not a Tamil Muslim (J.B.More,2004). After this several translations was done by Muslims and non-Muslims.

The Thousand and One Nights (also called The Arabian nights) was introduced popularly to Tamil peoples and got a good response from both Muslims and non-Muslims, so it continuously translating into Tamil by different authors for over three centuries. We divided the Tamil translation of Arabian nights as two,completetranslation, and partial translation. Sixteen complete translations and twelve partial translations were made in these three centuries. Some of the complete translations do not cover all stories of Arabian nights. Most of the readings did not mention the original text, which text was used and followed. So we confused the translation is made directly from Arabic or through English. The translators of Arabian nights in Tamilmostly from upper-middle-class like Desikar, Mudaliyar, Pillai, and Naidu. These classes are educated from the middle of the nineteenth century, and they were introduced to world literature through English. 
The upper-class Brahmins already educated and introduced to world literature, but they didn't do translate the Arabian nights, why it is an Islamic literary piece. At the same time, the publisher also interested to publish the Arabian nights; they published it without the name of the author(s) and did not awareness in translation.

\section{Children's Literature}

Children's stories start from the folk stories in Tamil. There were stories like the Madurai veeran story, Kaathavarayan story, etc., popular among people. Later, Vikramaadityan stories, Thenaliraaman stories, Eesop stories, and Alibaba,Alaudin, Sindubad are Arabian stories that came to Tamil. Among the children's stories, those who came from Arabic got its importance. There were many stories in Tamil adapted from A Thousand and one night.

When Tamil children's stories adaptation from thousand and one night, Tamil children received the stories very well. But there was strong opposition among the people as they were of ghost stories and magic stories, were against the real-life situation and also unfit and stepping stone for the intellectual growth of the children. In children's literature of Tamil, particularly in Novels, the influence of thousand and one nights. The characters of Alibaba, Aladin, and Sindbad were separately modified for the children. Quite a large number of stories have been produced in Tamil from Thousand and one night. Where bird and animal take to humans, and also man comes like animal, bird, fish, snake, etc., are some of the magic stories in Tamil. These are just adaptations from a thousand and one night.

Children's novels adaptation of Thousand and one night:

- Muthiah Thangaraj's Thangamalai

Mohini, Athisayakkuthirai, Arputhavalli,

Manthiravathiyin Mahal.

- Nagai Tharuman's Mayapuri Mannan.

- Perisamy Thooran's Mayakkallan, Nattiyarani,

Olaikkili, Nilappattu, Thambiyinthiramai, etc.

- Puvi Venthan's Pachchaypoothamum

payankara thevathaiyum, Thankakkoondu

Ilavarasi.

- Vandumama's Thangaththeevu,

Manthirakkuthirai, etc.,
This adaptation can be separated into two. The first one is to extract only the subject matter from thousands and nights. In this way, there are a lot of short stories and novels were written in Tamil, based on the subject matter of Thousand and nights. Let us take the structure and subject matter of thousands and nights. There is a children novel in Tamil, Mayakkallan by PerisamyThooran, which adapted the structure and subject matter of Thousand and nights. Mayakkalan, like Thousand and nights, involves many stories within a story and exemplifies magic in the subject matter.

Periasamy Thooran wrote the novel Mayakkallan. He produced a lot of children, stories, and novels. $\mathrm{He}$ is an exemplary scholar in Tamil children's literature. He was awarded "Padma vibushan" by the government of India for his writings. One can find the influence of thousands and nights in Mayakkallan. It follows the subject matter and structure of Thousand and nights. This novel is very popular among children. The principal character in this novel is Aathmarangan. He doesn't know his father and mother. Aathmarangan could become in any physical form of his choice. He transforms himself into various forms to reach his parents, who are on the top of the mountain. Mayakkallan is a Necromancer, comes to stop Aathmarangan from climbing the mountain. Now, both Mayakkallan and Aathmarangan agree; according to that if Aathmarangan, when Mayakkallan tells a story, Aathmarangan should not sleep, and if sleep. Aathmarangan would be dropped down. Athmarangan agrees for that. But he sleeps in the middle of the stories of Mayakkallan. so Mayakkallan brings him down to the ground. Aathmaraman's purpose in seeing his parents is unsuccessful. WheneverAathmaranganclaimsmountain, he transforms himself into a new body, and Mayakkallan also starts telling narrating new stories accordingly.

Athmarangan gives New Bodies and, at the Time, Start Anew the Story of Mayakkallan

\begin{tabular}{|c|c|c|}
\hline & $\begin{array}{c}\text { Athmarangan give } \\
\text { new bodies }\end{array}$ & $\begin{array}{c}\text { New stories of } \\
\text { Mayakkallan }\end{array}$ \\
\hline 1 & Grass & Main story \\
\hline 2 & Flower & $"$ \\
\hline 3 & Snake & $"$ \\
\hline
\end{tabular}




\begin{tabular}{|c|c|c|}
\hline 4 & Koel & $"$ \\
\hline 5 & Lion & \\
\hline 6 & Baby & Cinna babba \\
\hline 7 & 12 year children & Thanthirakkathai \\
\hline 8 & Student & ganamoorthy \\
\hline 9 & Spinster & paadunkuyil \\
\hline 10 & Warrtor & senkatru \\
\hline 11 & Landlord & Iyaare! anilaare! \\
\hline 12 & 40 year old woman & cattaiyadi \\
\hline 13 & Scientist & minsarapuri \\
\hline 14 & Old man & Ulunthuvadai \\
\hline 15 & A pious man & cittupperuman \\
\hline 16 & Sanyasi & maayakkurangu \\
\hline
\end{tabular}

Here, magic is found throughout the novel like Thousand and nights. A Thousand and nights strictly followed both subject matter and structure. Within the main story, Aathmarangan, eleven new stories are in chided. The novel is like; many stories are packed inside a big story.

\section{Tamil Cinema}

Thousand and one night's influence upon Three Tamil Films. The first one,'Alibaabavum naarpathu thirutarkalum' (Alibaba and forty thieves) it was released on 14.01.1956. The second one, 'Alavudinum arbutha vilakkum' (Alavudin and magic light) it was released on13.04.1979.The third one, 'Sindubad,' thesefilms are influenced by thousand and one night some message and logic.

In Alibaba, thousands and one night like stories with some differences. At the end of Alibaba story in thousand and one night when Markiana kills forty thieves, she pours boiling oil into the tin and kills the thieves. In the Tamil cinema Alibaba, she kills the forty thieves by rolling tin, one by one from the back door of the palace to the running water.

\section{Differences}

\begin{tabular}{|l|l|}
\hline \multicolumn{1}{|c|}{$\begin{array}{c}\text { Thousand and one } \\
\text { nights }\end{array}$} & Alibaba (Tamil movie) \\
\hline $\begin{array}{l}\text { Markiana is a slave } \\
\text { woman. }\end{array}$ & Markiana is not a slave. \\
\hline $\begin{array}{l}\text { In order to compensate } \\
\text { Markiana's faith, Alibaba } \\
\text { gives his son to Markiana } \\
\text { is marriage }\end{array}$ & $\begin{array}{l}\text { To compensate } \\
\text { Markiana's faith, Alibaba } \\
\text { marries Markiana. }\end{array}$ \\
\hline
\end{tabular}

Having heard that his elder brother Kasim was murdered into pieces by thieves in a cage, Alibaba travels in a donkey to search his elder brother.

Kasim travels on a horse while searching his elder brother.

\section{Conclusion}

The impact of Arabian night's stories in Tamil is found in different areas like children's novels and cinema. A few characters like Alibaba, Aladin, and Sindbad made big impacts on the Tamil cinema industry and children's literature. These writings in Tamil started only after 1945 . It reached the climax stage during 1970-1990. The influence in Tamil novels started in the 1890s, In A.D.1898 (A.H.1318), "Tamirapattanam" was written in Arabuttamil (Tamil wrote in Arabic script), which was adapted from Madinatun Nuhas of Arabian Nights. In the Tamil world, the impact of Arabian nights started through Tamil novel and later influenced into Tamil cinema and children's literature of Tamil. In this way, if we arrange in order of mostly influence of Arabian nights in Tamil, Tamil children's literature (Ten novels and thirty short stories), Tamil cinema (six movies), and finally Tamil novels (two).

\section{References}

Afdalul Ulama and Tayka Shuayb Alim. Arabic, Arwi and Persian in Sarandib and Tamilnadu, Al- Imam Al-Aroos Trust Publication, 1993.

Richard F. Burton. Tales from 1001 Arabian Nights (Translation and Annotation), Jaico Publishing House, 2008.

Poovannan. History of Children Literature in Tamil, Manivasakar Publication, 1999.

Poovannan. Poets of Children in Tamil, Manivasakar Publication, 2000.

Prashant More, J.B. Muslim Identity, Print Culture, and the Dravidian Factor in Tamil Nadu, Oriental Longman Private Limited, 2004.

\section{Appendix - I: List of Tamil translations of Arabian nights 19th Century Translation \\ Desikar Arumuga, Arabikkathaikal, 1888. Mudali Annasamy, Arabikkathaikal, 1875.}


Mudaliyar Arumuga, Aayiraththooru Iravugal, 1880.

Mudaliyar Ganaprakasa. P. Manathaimagilvikkum Arabia Iravukal (Arabian Nights Entertainment), 1825.

Pillai, Singaram Palavendra. Anubhandha Arabikkathaikal (connected Arabic stories), 1880 ,

Arabikkathaikal (Arabian stories), 1880.

Yavana Yaminivinothankal (bizarre of Arabian nights), 1886.

\section{0th Century Translation}

Ibrahim Syed, Arabunaattukkathaikal (stories of Arabian countries), 1960.

Marichamy. S.S., Ayiraththoru Iravukal, (Thousand and One nights), 1953.

Muthiah Mullai, Ayiraththoru Iravukal (Thousand and One nights), 1977.

Mudaliyar Selvagesavaraya. T., Arabiyakkathaikal (Arabian stories), 1918.

Natarajan, A.L., Ayiraththotu Iravukalentra Arabukkathaikal, 1958.

Pillai Appadurai, M.R., Ayiraththoru Iravilcolliya Arabukkathaikal, 1953.

Sha Alhaj Dawood. Alflailawalaila (1001 Arabian nights), 1953,

Parathan. M.S., Ayiraththoru Iravilcolliya Arabukkathaikal, 1977.

\section{1st Century Translation}

Janarthanan, N. Ayiraththoru Arabia Iravukal (1001 Arabian nights), 2009.

\section{Translation of some parts of Arabian nights}

Ashokkumar, Alavudinarbuthavilakku, Kavitha Publication, Chennai.

Baccayannan. A.K., Sindubadin katarpayanankal, Ashokan Publication, 2001.

Deivasikamani. N.C., Alibaabavum naarbathu thirutarkalum (Alibaba and 40 thieves), Kannappan Publication, 2009.

Pillai Sankaranlingam. A., Allaudinallathu Arbuthadeepam (Allaudin or bright light), C. Kumarasamy Naidu and sons, 1912.
Ramaswamy, Alibaabaa, Palaniyappa Brothers, 2002.

Thulasi and Babaraj Mathurai., Manathaikkavarum Arabiyakkathaikal, Apple Publishing International (P) Ltd, 2007.

Alavudinarbuthavilakku, Kavitha Publication.

Alibaba, Kazaignan Publication.

Alibabavum 40 Thirudarkalum (Alibaba and forty Thieves), Kazaignan Publication.

Sindubad Story, Manimekalai Publication.

Sindubad, Kazaignan Publication.

\section{Appendix - II: List of Adaptation of Arabian nights in Tamil \\ In Children's novels of Tamil}

Mohanarangan, K. Aalandoor., Chandra mandalaththil manthiravathy.

Magilchchikkannan., Thangameen.

Poovannan, Erimalaiarakkan.

Thankakkoondu Ilavarasi.

Raji, Thangamaambalam.

Santhanu, Vethalaulakilveechchu.

Thangaraj Muthiah., Thangamalai Mohini, Athisayakkuthirai, Arputhavalli, Manthiravathiyin Mahal.

Tharuman Nagai, Mayapuri Mannan.

ThooranPerisamy, Nattiya rani.

----, Olaikkili.

----, Nilappattu.

----, Thambiyinthiramai.

Vandumama, Thangaththevu, Manthirakkuthirai etc.

\section{In Tamil Cinema}

Alibabavum 40 Thirudarkalum (Alibaba and forty Thieves), 1956.

Allavudeenum Arpudha Villakkum (Aladin and bright light), 1957.

Allavutheenum Arputha Vilakkum (Aladin and bright light), 1979.

Sindhupath, 1995.

Alaudin, 2003.

Alibaba, 2008.

\section{Author Details}

D. Sundararaj, Assistant Professor, Department of Tamil, KR College of Arts \& Science, Kovilpatti, Tamil Nadu, India, Email ID: sundarasu@gmail.com 